\title{
Original article: \\ The Effects Comparisons of Sauropus androgynous, Moringa oleiefera alone and in combination on iron deficiency in anemia rats \\ Ulfah Dian Indrayani $^{1^{*}}$, Hadi Sarosa ${ }^{2}$, Atina Hussaana ${ }^{3}$, Bagas Widiyanto ${ }^{3}$
}

\begin{abstract}
$\underline{\text { Abstract }}$
Background: Leaves extract of Sauropus androgynous (Sa) or Moringaoleiefera(Mo) alone has been shown to increase hemoglobin level in iron deficiency anemia. The combination of the two extracts have been known to potentially have a synergistic effect on anemia. The objective of this study is to compare the anti-anemic effect of Sa, Mo alone and their combination on iron deficiency anemia in rats. Methods: Thirty female wistarstrain rats were randomly divided into 5 groups: normal, iron deficiency anemia, Sa, Mo and the combination of Sa and Mo. Beside the normal group, rats were fed Fe-deficient diet to induce iron-deficiency anemia. Level of hemoglobin, ferritin and plasma MDA were measured on day 8 (after induction of anemia) and day 29. Data were analyzed using One Way ANOVA followed by LSD post hoc test. Result: The rats fed with Fe-deficient diet for 7 days shown significantly had a lower plasma $\mathrm{Hb}$ and ferritin levels and higher plasma MDA levels compared to the normal group $(p<0.05)$ After the treatment, the rats given the extracts significantly had a higher mean of $\mathrm{Hb}$ and Ferritin and a lower mean of MDA level compared to anemic control. The mean Hb, ferritin and MDA level of the combination group were close to normal group. Conclusion: The combination of the leaves extract of Sauropus androgynous or Moringaoleiefera is more effective against iron deficiency anemia compared to extract alone in rats.
\end{abstract}

Keyword: Sauropus androgynous extract; Moringaoleiefera extract; Combination extract; antianemia

Bangladesh Journal of Medical Science Vol. 18 No. 01 January'19. Page : 136-140 DOI: https://doi.org/10.3329/bjms.v18i1.39564

\section{Introduction}

Anemia is still become health concern in Indonesia ${ }^{1-3}$. A study conducted by National Health survey (RISKESDAS) in 2013 showed that anemia in children under five years of age, pregnant women and the elderly in Indonesia were $28.1 \% ; 37.1 \%$ and $44.2 \%$, respectively ${ }^{4}$. The proportion of iron deficiency anemia in pre-school age children and women at reproductive age ranged from $25 \%$ and $37 \%$ respectively 5 . Several studies have shown that untreated iron deficiency anemia can have a serious impact on health ${ }^{6-11}$.
The standard therapy for Nevertheless, some studies suggested that iron tablet supplementations may cause gastrointestinal complaints such as nausea, constipation or significant diarrhea $^{12,14}$. Deficiency and excess of Fe can cause cell damage through oxidative stress ${ }^{15-18}$. The medium and high dose Fe supplementation for 4 weeks has been shown to increase in oxidative stress characterized by elevated levels of MDA in anemia-induced mice ${ }^{15}$. Antioxidant supplementation of vitamin $\mathrm{C}$ and $\mathrm{E}$ in patients with iron deficiency anemia for 15 days

1. Ulfah Dian Indrayani, Department of Histology, Faculty of Medicine, Sultan Agung Islamic University, Semarang, Indonesia;

2. Hadi Sarosa, Department of Physiology Faculty of Medicine Sultan Agung Islamic University, Semarang, Indonesia;

3. Atina Hussaana, Department of Pharmacology, Faculty of Medicine, Sultan Agung Islamic University, Semarang, Indonesia

4. Bagas Widiyanto, Department of Pharmacology, Faculty of Medicine, Sultan Agung Islamic University, Semarang, Indonesia

Correspondence to: Ulfah Dian Indrayani, J1. Raya Kaligawe KM. 4 PO BOX 1054 Semarang Jawa Tengah Indonesia, Email : ulfahdian@gmail.com 
decreases plasma $\mathrm{MDA}^{17}$.

Indonesia has a lot of plants with potential for antianemia and antioxidants therapy, such as Sauropus androgynous and Moringa oleiefera ${ }^{19-21}$. Sauropus androgynous and Moringa oleiefera leaves are commonly consumed as leafy vegetable. These plants are easy to be found and used. Sauropus androgynous leaves contain higher Fe than Moringa oleiefera. However, the utilization of Sauropus androgynous leaves as antianemia therapy should consider the safety range of the dose. There was a report on that outbreak of bronchiolitis obliterans after the consumption of Sauropus androgynous leaf juice ${ }^{22}$.

Sauropus androgynous and Moringa oleiefera leaf have a complementary macronutrient and micronutrient compositions. The composition of minerals and vitamins per $100 \mathrm{~g}$ of fresh leaf of Sauropus androgynous contains $8.8 \mathrm{mg} \mathrm{Fe}, 543 \mathrm{mg} \mathrm{P}, 771$ $\mathrm{mg}$ Ca $5600 \mathrm{mg}$ carotene, $0.50 \mathrm{mg}$ thiamine, 244 $\mathrm{mg}$ vitamin $\mathrm{C}$ and $0.21 \mathrm{mg}$ riboflavin while 100 g Moringa oleifera fresh leaves contains $7 \mathrm{mg}$ Fe, $70 \mathrm{mg} \mathrm{P}, 440 \mathrm{mg} \mathrm{Ca}, 6780 \mathrm{mg}$ carotene, 0.07 $\mathrm{mg}$ thiamine, $240 \mathrm{mg}$ vitamin $\mathrm{C}$ and $0.39 \mathrm{mg}$ riboflavin(22). Moringa oleifera leaves also contain a higher total phenolic, flavonoid and ascorbic acid than its fruit and seeds. Moringa oleifera, respectively of $105.04 \mathrm{mg}$ galicequivalen acid (GAE) / g 31.28 quercetin equivalent (QE) / $\mathrm{g}$ and $106.95 \mathrm{mg} / 100 \mathrm{~g}^{23}$. Some studies have proven antioxidant potential of Moringa oleifera leaves against free radicals and prevent oxidative stress ${ }^{24,25}$. The combination of Sauropus androgynous leaf extract and Moringa oleifera leaves may have a synergistic effect on anemia and become an alternative to $\mathrm{Fe}$ supplementation. This study was aimed to compare the antianemiceffect of Moringa oleiferaand Sauropus androgynous leaf extract alone and their combination.

\section{Methods}

\section{Induction of iron deficiency anemia in rats}

Thirty female wistar strain rats weighed 190-220 g were adapted for 7 days then randomly divided into 5 groups: normal, iron deficiency anemia (IDA), Sauropus androgynous (Sa), Moringa oleiefera (Mo) and combination of Sauropus androgynous and Moringa oleiefera (SaMo). Each group consisted of 6 rats. The rats were fed with iron-deficiency diet (AIN-93 M) for 7 days ${ }^{11}$ while 6 rats in the normal group were given a standard diet.

\section{Plasma collection and analysis}

The blood samples were obtained from blood orbital sinus on day 8 and day 29. Blood samples added with heparin were centrifuged and the plasma were stored at $-20{ }^{\circ} \mathrm{C}$ for further analysis. cyanmethhemoglobin hemoglobin and ferritin concentration were evaluated with spectrophotometer. MDA level was evaluated with barbituric thio acid reactive system (TBARS) using a spectrophotometer. Measurements were conducted at the Center for Food and Nutrition Studies of Gadjah Mada University Yogyakarta.

\section{Dose of Extract}

Dosage used for leaf extract of Sauropus androgynous was $300 \mathrm{mg} / \mathrm{day}$, while the leaf extract of Moringa oleiefera was $80 \mathrm{mg} /$ day. The combination extract consists the combinations of Sauropus androgynous (150 mg/day) and Moringa oleiefera $(40 \mathrm{mg} /$ day) . The extracts were prepared with a $70 \%$ ethanol using maceration method. The leaves were obtained from Sleman, Yogyakarta Indonesia.

\section{Statistical analysis}

Statistical analysis for mean differences of hemoglobin and MDA before and after the treatment were analyzed using One Way ANOVA test followed by LSD Post Hoc test with a significance value of $p<0.005$ (table 1). The mean difference in hemoglobinserum, ferritin and MDA level prior to the treatment with extract were analyzed with Kruskal Wallis test followed by Mann Whitney test with significance value of $p<0.005$ (table 1 ). The mean difference of hemoglobin, serum ferritin and MDA level in each group before extract and after administration of extract was analyzed using paired sample T-Test.

\section{Ethical clearance}

The ethical clearance for this research was obtained from Bioethics Commission of Medical / Health Research Faculty of Medicine Sultan Agung Islamic University Number 01/I/2018 / Bioethics Commission

\section{$\underline{\text { Results }}$}

The mean of hemoglobin and ferritin level in iron deficiency anemia (IDA), Sauropus androgynous ( $\mathrm{Sa}$ ), Moringa oleiefera (Mo ) and combination of Sauropus androgynous and Moringa oleiefera (SaMo ) fed with iron deficient diet for 7 days was significantly lower than those of the normal group. In contrast, the mean MDA levels in the IDA, Sa, Mo and SaMo groups fed with iron 
deficient diet for 7 days was higher and significantly different from those of normal group. The mean haemoglobin, ferritin serum and MDA level in IDA, Sa, M o and SaMo combination fed with iron deficient for 7 days did not show significant differences (Table 1)

After the treatment for 21 days, the mean of hemoglobin and ferritin levels in the 3 treatment groups were higher than IDA group and lower than the normal group. In contrast, the mean MDA in the treatment group showed a lower concentration than the IDA group, but higher than normal group (Table 1). The mean hemoglobin, ferritin and MDA after administration of the combination SaMo extract has been shown to be comparable to that of normal group. Likewise, the highest mean difference of hemoglobin and ferritin was found in the group given the combination extract SaMo. The mean difference in hemoglobin and ferritin in Sauropus androgynous group was higher than that of in Moringa oleiefera.

Table 1 .Mean and Standard Deviation of Hemoglobin, Ferritin and MDA level

\begin{tabular}{|c|c|c|c|c|c|c|c|}
\hline Variables & Time & Normal & IDA & $\mathbf{S a}$ & Mo & $\begin{array}{l}\text { Combination of } \\
\text { SaMo }\end{array}$ & $\mathbf{p}$ \\
\hline \multirow{3}{*}{$\begin{array}{l}\mathrm{Hb} \\
(\mathrm{g} / \mathrm{dl})\end{array}$} & D-8 & $14 \pm 0.14^{\mathrm{a}}$ & $\begin{array}{l}9.2 \pm \\
0.34^{\mathrm{b}}\end{array}$ & $8.8 \pm 0.39^{b}$ & $\begin{array}{l}9.15 \pm \\
0.32^{\mathrm{b}}\end{array}$ & $9.08 \pm 0.16^{\mathrm{b}}$ & $0.180^{*}$ \\
\hline & D-29 & $13.7 \pm 0.29^{a}$ & $\begin{array}{l}8.9 \pm \\
0.27^{b}\end{array}$ & $\begin{array}{l}12.02 \pm \\
0.26^{c}\end{array}$ & $\begin{array}{l}10.57 \pm \\
0.33^{\mathrm{d}}\end{array}$ & $12.81 \pm 0,18^{\mathrm{e}}$ & $0.000 *$ \\
\hline & $\Delta$ & $\begin{array}{l}-0.29 \pm \\
0.19^{\mathrm{a}}\end{array}$ & $\begin{array}{l}-0.25 \pm \\
0.12^{\mathrm{a}}\end{array}$ & $\begin{array}{l}3.21 \pm \\
0.58^{\mathrm{b}}\end{array}$ & $\begin{array}{l}1.42 \pm \\
0.55^{\mathrm{c}}\end{array}$ & $3.37 \pm 0.24^{\mathrm{b}}$ & $0.000 * *$ \\
\hline \multirow{3}{*}{$\begin{array}{l}\text { Ferritin } \\
(\mu \mathrm{g} / \mathrm{l})\end{array}$} & D-8 & $41.6 \pm 0.93^{\mathrm{a}}$ & $\begin{array}{l}9.3 \pm \\
0.48^{b}\end{array}$ & $\begin{array}{l}10.06 \pm \\
0.20^{\mathrm{b}}\end{array}$ & $\begin{array}{l}9.73 \pm \\
0.83^{\mathrm{b}}\end{array}$ & $9.69 \pm 0.83^{b}$ & $0.212 * *$ \\
\hline & D-29 & $\begin{array}{l}40.73 \pm \\
1.06^{\mathrm{a}}\end{array}$ & $\begin{array}{l}9.21 \pm \\
0.48^{\mathrm{b}}\end{array}$ & $\begin{array}{l}35.39 \pm \\
0.38^{\mathrm{c}}\end{array}$ & $33.9 \pm 0.3^{\mathrm{d}}$ & $39.15 \pm 0.51^{\mathrm{e}}$ & $0.000^{*}$ \\
\hline & $\Delta$ & $\begin{array}{l}-0.87 \pm \\
0.60^{\mathrm{a}}\end{array}$ & $\begin{array}{l}-0.16 \pm \\
0.19^{\mathrm{b}}\end{array}$ & $\begin{array}{l}25.33 \pm \\
0.52^{\mathrm{c}}\end{array}$ & $\begin{array}{l}24.17 \pm \\
1.30^{c}\end{array}$ & $29.46 \pm 0.94^{\mathrm{d}}$ & $0.000 * *$ \\
\hline \multirow{3}{*}{$\begin{array}{l}\text { MDA } \\
(\mathrm{nmol} / \mathrm{ml})\end{array}$} & D-8 & $\begin{array}{l}1.64 \pm \\
0.13^{\mathrm{a}}\end{array}$ & $\begin{array}{l}8.1 \pm \\
0.24^{\mathrm{b}}\end{array}$ & $\begin{array}{l}8.16 \pm \\
0.46^{\mathrm{b}}\end{array}$ & $8.1 \pm 0.22^{b}$ & $8.19 \pm 0.33^{b}$ & $0.961^{*}$ \\
\hline & D-29 & $\begin{array}{l}1.83 \pm \\
0.12^{\mathrm{a}}\end{array}$ & $\begin{array}{l}8.3 \pm \\
0.21^{\mathrm{b}}\end{array}$ & $\begin{array}{l}2.92 \pm \\
0.20^{c}\end{array}$ & $3.6 \pm 0.15^{\mathrm{d}}$ & $\begin{array}{l}2.3 \pm \\
0.16^{\mathrm{e}}\end{array}$ & $0.000^{*}$ \\
\hline & $\Delta$ & $\begin{array}{l}0.20 \pm \\
0.11\end{array}$ & $\begin{array}{l}0.20 \pm \\
0.14\end{array}$ & $\begin{array}{ll}-5.23 & + \\
0.65 & \end{array}$ & $\begin{array}{l}-4.50 \pm \\
0.37\end{array}$ & $-5.82+0.46$ & $0.000 *$ \\
\hline
\end{tabular}

* One Way Anova test, **Kruskal Walis test. At D-8 the value of $\mathrm{p}$ between the IDA, Sa, Mo and combination groups, when compared to the normal group then $\mathrm{p}=0.000$. Different letters indicatesignificant differences $\mathrm{p}<0.005$

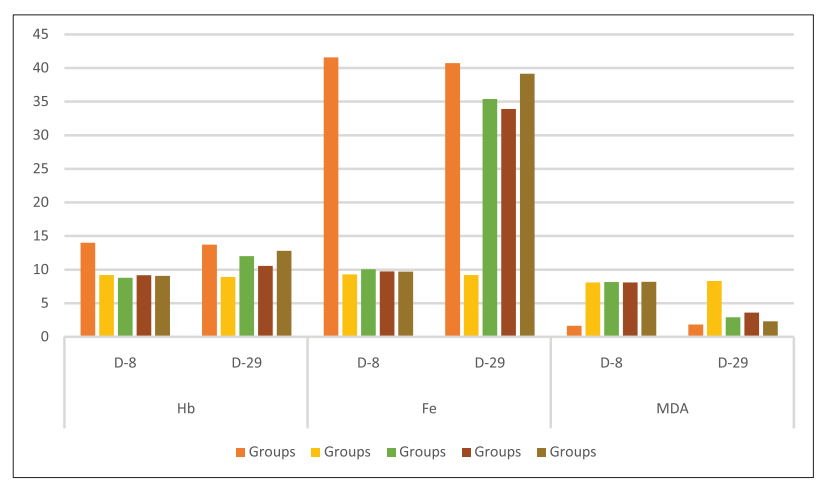

Figure 1. Mean hemoglobin $\mathrm{h}(\mathrm{g} / \mathrm{dl})$, ferritin $(\mu \mathrm{g} / \mathrm{l})$ and MDA (nmol / ml) before (D-8) and after (D-29) the administration of extract alone and in combination. Paired T-Test $\mathrm{p}<0.005$

\section{Discussion}

Iron is a major component needed in the formation of hemoglobin and erythropoiesis. In this currentstudy, induction of AIN93 -M-MX deficiency diet for 7 days were success in making iron deficiency in anemia rats marked by decreased level of serum hemoglobin and ferritin concentration by $35 \%$ and $77 \%$ respectively compared to the normal group given standard diet . Serum ferritin is an indicator that leads to iron storage in the body, where $1 \mu \mathrm{g} / \mathrm{L}$ of serum ferritin is equivalent to $120 \mu \mathrm{g}$ of iron deposits per $\mathrm{kg}$ body weight. The decrease of serum ferritin signifies an iron depletion.

Sauropus androgynous leaves containing chlorophyll 
have been shown to have antiemetic effect in female rats induced by sodium dinitrate, while the administration of Moringa oleiefera leaves also have been shown to have higher anti-anemic activity compared to iron tablet supplementation ${ }^{21}$. This may be due to the Fe content in fresh leaves of Sauropus androgynous higher than fresh leaves Moringa oleiefera. In this study, the administration of combination leaf extract of androgynous Sauropus and Moringa oleiefera for 21 days may increase mean haemoglobin and ferritin plasma in anemic rats. However, in this study, the number of Fe in each extract was no established. Interestingly, in the combination group of Sauropus androgynous leaves - Moringa oleiefera was found to have the highest increase by $41.08 \%$ and $75.25 \%$ respectively. The combination of Sauropus androgynous leaves and Moringa oleiefera may have a synergistic effect on anemia. The previous study showed that the $35 \mathrm{mg}$ Fe diet from Moringa oleiefera effect on gene expression of liver hepcidin, transferrin, TRF-2, and ceruloplasmin ${ }^{21}$.

Iron is required for the production of hemoglobin. The decrease of hemoglobin will cause the decrease of oxygen concentration in the body that can cause hypoxia. Hypoxia leads to oxidative stress. In iron deficiency anemia the concentration of SOD, CAT and GPx antioxidant enzymes are decreased ${ }^{17,26,27}$. Hypoxia and decreased concentrations of antioxidant enzymes play a role in lipid peroxidation and oxidative stress in erythrocytes. Oxidative stress on the erythrocyte membrane can cause erythrocytes in iron deficiency anemia to have higher rigidity than normal cells ${ }^{28}$ so that erythrocyte is prone to undergo eryptosis ${ }^{29}$. The degree of oxidative stress in this study was measured from the concentration of malondialdehyde (MDA).

On the other hand, post- supplementation of $\mathrm{Fe}$ tablets indicated an increase in lipid peroxidation through fenton reactions, damaging proteins and nucleic acids and causing oxidative stress $(15,30)$. Previous research shown that supplementation of Fe tablets at the dose of $4.8 \mathrm{mg} / 100 \mathrm{~g} \mathrm{BW}$ for 4 weeks increase MDA concentration of rat liver and decrease SOD concentration and $\mathrm{GPx}^{15}$. The addition of antioxidant vitamins $\mathrm{A}, \mathrm{C}$ and $\mathrm{E}$ in $\mathrm{Fe}$ supplementations can decrease MDA concentration and increase the concentration of GPx enzyme ${ }^{17}$.

Supplementation of combination extract of Sauropus androgynous-Moringa oleieferaleaves for 21 days can lowered the MDA concentration by $71.19 \%$. These effects may be associated with a higher increase in $\mathrm{Hb}$ levels in the combination group so as to bind more oxygen than the extract alone. In addition, these effects may be correlated with antioxidant components of Sauropus androgynousMoringa oleieferaleaves extract combination.

\section{Conclusion}

The combination of the leaves extract ofSauropusandrogynous and Moringa oleiefera (SaMo) had increase hemoglobin and ferritin and lower MDA level compared to single extract in diet anemia-induced rats.

\section{Acknowledgement}

This research was funded by the Faculty of Medicine, Sultan Agung Islamic University through an internal research program in 2017/2018.

\section{Conflict of interest}

The researcher has no conflict of interest in this publication

\section{Contribution of authors:}

Data and gathering and idea owner of this study : Ulfah Dian Indrayani

Study design: Ulfah Dian Indrayani

Data gathering: Ulfah Dian Indrayani, Atina Hussaana Writing and submission of manuscript: Ulfah Dian Indrayani, Hadi Sarosa, Atina Hussaana, Bagas Widiyanto

Editing and approval of final draft: Ulfah Dian Indrayani

\section{Reference:}

1. Widjaja IR, Widjaja FF, Santoso LA, Wonggokusuma E. Anemia among children and adolescents in a rural area. Paediatr Indones. 2014;54(2):88-93. https://doi.org/10.14238/pi54.2.2014.88-93

2. Barkley JS, Kendrick KL, Codling K, Muslimatun S, Pachón H. Anaemia prevalence over time in Indonesia: Estimates from the 1997, 2000, and 2008
Indonesia Family Life Surveys. Asia Pac J Clin Nutr. 2015;24(3):452-5.

3. World Health Organization. the Global Prevalence of Anaemia in 2011. WHO Rep [Internet]. 2011;48. Available from: http://apps.who.int/iris/ bitstream/10665/177094/1/9789241564960_eng. pdf?ua $=1$

4. Badan Pengembangan dan Penelitian Kesehatan 
Ulfah Dian Indrayani, Hadi Sarosa, Atina Hussaana, Bagas Widiyanto

Kementerian Kesehatan RI. RISET KESEHATAN DASAR. Badan Penelitian dan Pengembangan KEsehatan Kementerian Kesehatan RI; 2013.

5. Petry N, Olofin I, Hurrell RF, Boy E, Wirth JP, Moursi $\mathrm{M}$, et al. The proportion of anemia associated with iron deficiency in low, medium, and high human development index countries: A systematic analysis of national surveys. Nutrients. 2016;8(11):1-17. https://doi.org/10.3390/nu8110693

6. Zimmermann MB, Köhrle J. The Impact of Iron and Selenium Deficiencies on Iodine and Thyroid Metabolism: Biochemistry and Relevance to Public Health. Thyroid [Internet]. 2002;12(10):86778. Available from: http://www.liebertonline. $\mathrm{com} / \mathrm{doi} / \mathrm{abs} / 10.1089 / 105072502761016494$ https://doi.org/10.1089/105072502761016494

7. Lozoff B, Beard J, Connor J, Felt B, Georgieff M, Schallert T. Long-lasting neural and behavioral effects of iron deficiency in infancy. Nutr Rev [Internet]. 2006;64(5 Pt 2):S34-43-91. Available from: http://www. pubmedcentral.nih.gov/articlerender.fcgi?artid=154044 $7 \&$ tool $=$ pmcentrez\&rendertype $=$ abstract

8. Charles C V. Iron Deficiency Anemia : A Public Health Problem of Global Proportions. Methodol Environ Syst Issues, 2012;109-30.

9. Hassan TH, Badr MA, Karam NA, Zkaria M, El Saadany HF, Rahman DMA, et al. Impact of iron deficiency anemia on the function of the immune system in children. Med (United States). 2016;95(47):1-5. https://doi.org/10.1097/MD.0000000000005395

10. Algarín C, Peirano P, Garrido M, Pizarro F, Lozoff B. Iron deficiency anemia in infancy: Longlasting effects on auditory and visual system functioning. Pediatr Res. 2003;53(2):217-23. https://doi.org/10.1203/01.PDR.0000047657.23156.55

11. Vieyra-reyes $\mathrm{P}$, Millán-aldaco D, Palomero-rivero $\mathrm{M}$, Jiménez-garcés C, Hernández-gonzález M, Caballerovillarraso J. An iron-deficient diet during development induces oxidative stress in relation to age and gender in Wistar rats. J Physiol Biochem [Internet]. 2016; Available from: $\quad$ http://dx.doi.org/10.1007/s13105-016-0529-x https://doi.org/10.1007/s13105-016-0529-x

12. Cook JD. Diagnosis and management of iron-deficiency anaemia. Best Pract Res Clin Haematol. 2005;18(2 SPEC. ISS.):319-32.

13. Pasricha SR, Hayes E, Kalumba K, Biggs BA. Effect of daily iron supplementation on health in children aged 4-23 months: A systematic review and metaanalysis of randomised controlled trials. Lancet Glob Heal [Internet]. 2013;1(2):e77-86. Available from: http://dx.doi.org/10.1016/S2214-109X(13)70046-9 https://doi.org/10.1016/S2214-109X(13)70046-9

14. Tolkien Z, Stecher L, Mander AP, Pereira DIA, Powell JJ. Ferrous sulfate supplementation causes significant gastrointestinal side-effects in adults: A systematic review and meta-analysis. PLoS One. 2015;10(2):1-20. https://doi.org/10.1371/journal.pone.0117383

15. Ma J, Wen X, Mo F, Wang X. Effects of Different Doses and Duration of Iron Supplementation on Curing Iron Deficiency Anemia : an Experimental Study. 2014;(800):242-51.

16. Rifkind JM. Iron-Deficiency Anemia Enhances Red Blood Cell Oxidative Stress Enika. Free Radic Res. 2008;42(9):824-9. https://doi.org/10.1080/10715760802459879

17. Madhikarmi NL, Rudraiah K, Murthy S. Antioxidant Enzymes and Oxidative Stress in the Erythrocytes of Iron Deficiency Anemic Patients Supplemented with
Vitamins. 2014;18(April):82-7.

18. Madhikarmi NL, Murthy KRS. Effect of iron deficiency anemia on lipid peroxidation and antioxidant systems. 2011;(4):34-43.

19. Adnyana IK, Al E. Pengaruh Pemberian Jus Daun Katuk, Jus Daun Ubi Jalar, dan Kefir Terhadap Profil Hematologi Mencit Anemia yang Diinduksi Alumunium Sulfat. Acta Pharm Indones. 2012;XXXVII(2):54-8.

20. S S, Sampurna S, C.S NA, Ednisari AM, Urfani GD, Laila I, et al. Anti-anemia Effect of Chlorophyll from Katuk (Sauropus androgynus) Leaves on Female Mice Induced Sodium Nitrite. Pharmacogn J [Internet]. 2016;8(4):375-9. Available from: http://phcogj.com/ article/ 165

21. Saini RK, Manoj P, Shetty NP, Srinivasan K, Giridhar P. ScienceDirect Dietary iron supplements and Moringa oleifera leaves influence the liver hepcidin messenger RNA expression and biochemical indices of iron status in rats. Nutr Res [Internet]. 2014;34(7):630-8. Available from: http://dx.doi.org/10.1016/j.nutres.2014.07.003 https://doi.org/10.1016/j.nutres.2014.07.003

22. Padmavathi P, Rao MP. Nutritive value of Sauropus androgynus leaves. Plant Foods Hum Nutr. 1990;40(2):107-13. https://doi.org/10.1007/BF02193767

23. Singh BN, Singh BR, Singh RL, Prakash D, Dhakarey $\mathrm{R}$, Upadhyay $\mathrm{G}$, et al. Oxidative DNA damage protective activity, antioxidant and anti-quorum sensing potentials of Moringa oleifera. Food Chem Toxicol [Internet]. 2009;47(6):1109-16. Available from: $\quad$ http://dx.doi.org/10.1016/j.fct.2009.01.034 https://doi.org/10.1016/j.fct.2009.01.034

24. Sreelatha S, Padma PR. Antioxidant activity and total phenolic content of Moringa oleifera leaves in two stages of maturity. Plant Foods Hum Nutr. 2009;64(4):303-11. https://doi.org/10.1007/s11130-009-0141-0

25. Aa A, Om J, Ts E, Ga A. Preliminary phytochemical screening, antioxidant and anti- hyperglycaemic activity of Moringa oleifera leaf extracts. 2013;2217-23.

26. Lazarte SS, Mónaco ME, Jimenez CL, Emilse M, Achem L, Terán MM, et al. Erythrocyte Catalase Activity in More Frequent Microcytic Hypochromic Anemia: Beta-Thalassemia Trait and Iron Deficiency Anemia. 2015;2015.

27. Ariyurek SY, Aksoy K. Effect of Oxidative Stress on Membrane Proteins in Thalassemia and Iron Deficiency Anemia. 2012;79(June):755-8.

28. Brandão MM, Lourdes M De, Castro RB, Fontes A, Cesar CL. Impaired red cell deformability in iron deficient subjects. 2009;43:219-23.

29. Lang E, Lang F. Mechanisms and pathophysiological significance of eryptosis, the suicidal erythrocyte death. Semin Cell Dev Biol [Internet]. 2015;1-8. Available from: http://dx.doi.org/10.1016/j.semcdb.2015.01.009 https://doi.org/10.1016/j.semcdb.2015.01.009

30. Article O, Zaka-ur-rab Z, Adnan M, Ahmad SM, Islam N. Effect of Oral Iron on Markers of Oxidative Stress and Antioxidant Status in Children with Iron Deficiency Anaemia. 2016; 